\title{
Production and consumption of dimethylsulfide (DMS) in North Atlantic waters
}

\author{
M. G. Scarratt ${ }^{1, *}$, M. Levasseur ${ }^{1}$, S. Schultes $^{1,2, * *}$, S. Michaud $^{1}$, G. Cantin${ }^{1}$, \\ A. Vézina ${ }^{1, * * *}$, M. Gosselin ${ }^{2}$, S. J. de Mora ${ }^{2, * * * *}$ \\ ${ }^{1}$ Fisheries and Oceans Canada, Maurice Lamontagne Institute, 850 Route de la mer, Mont-Joli, Quebec G5H 3Z4, Canada \\ ${ }^{2}$ Institut des sciences de la mer (ISMER), Université du Québec à Rimouski, 310 Allée des Ursulines, Rimouski, \\ Quebec G5L 3A1, Canada
}

\begin{abstract}
Production and consumption of dimethylsulfide (DMS) were studied in surface waters of the northwest Atlantic between latitude $32^{\circ}$ and $45^{\circ} \mathrm{N}$ during May 1998. The kinetics of DMS production by the whole planktonic community were studied in short-term $(3 \mathrm{~h})$ experiments using additions of dissolved dimethylsulfoniopropionate $\left(\mathrm{DMSP}_{\mathrm{d}}\right)(0$ to $3000 \mathrm{nM})$. Measurements of DMS production and $\mathrm{DMSP}_{\mathrm{d}}$ consumption showed that the DMS production rate increased in direct proportion to the concentration of added $\mathrm{DMSP}_{\mathrm{d}}$. This rate relationship did not saturate, suggesting acclimation of the microbial community to $\mathrm{DMSP}_{\mathrm{d}}$ concentrations much higher than the average for bulk seawater. Longer-term experiments were performed in which $\mathrm{DMSP}_{\mathrm{d}}$ consumption and DMS production were measured over 48 to $60 \mathrm{~h}$. The $\mathrm{DMSP}_{\mathrm{d}}$ consumption rate decreased as the concentration of $\mathrm{DMSP}_{\mathrm{d}}$ decreased during the incubations. However, the DMS production rate was initially constant for the first $36 \mathrm{~h}$. When $\mathrm{DMSP}_{\mathrm{d}}$ concentrations fell below $50 \mathrm{nM}$, DMS production stopped, even though $\mathrm{DMSP}_{\mathrm{d}}$ consumption continued. A possible explanation is that DMSP cleavage might dominate the total DMSP consumption at high DMSP $_{d}$ concentrations while DMSP demethylation and other processes dominate at low $\mathrm{DMSP}_{\mathrm{d}}$ concentrations. DMS consumption was measured both directly and by using the DMS consumption inhibitors dimethyl disulfide (DMDS) and methyl butyl ether (MBE). DMS consumption was generally undetectable except at 1 station dominated by a dense population of the DMSP-producing phytoplankton Chrysochromulina sp. and where ambient DMS concentrations were high. This suggests that the potential for DMS consumption is highest where ambient DMS levels are elevated. Pooling results from these experiments with earlier results from more northerly waters revealed an inverse exponential relationship $\left(r^{2}=0.75, p<0.0001\right)$ between the potential rate constant and chlorophyll a standing stock across a wide area of the Northwest Atlantic. This finding is potentially useful for the development of DMS production models.
\end{abstract}

KEY WORDS: Dimethylsulfide · DMS · Dimethylsulfoniopropionate · DMSP · Sulfur · Bacteria · North Atlantic Resale or republication not permitted without written consent of the publisher

${ }^{*}$ E-mail: scarrattm@dfo-mpo.gc.ca

Present addresses:

**Biological Oceanography, Alfred-Wegener Institute for Polar and Marine Research, Am Handelshafen 12, 27570 Bremerhaven, Germany

${ }^{* * *}$ Fisheries and Oceans Canada, Bedford Institute of Oceanography, Dartmouth, Nova Scotia B2Y 4A2, Canada

${ }^{* * * *}$ International Atomic Energy Agency, Marine Environmental Laboratory, 4 Quai Antoine $1^{\mathrm{er}}$, BP 800, 98021 Monaco

\section{INTRODUCTION}

Dimethylsulfide (DMS) and its precursor, dimethylsulfoniopropionate (DMSP), along with dimethylsulfoxide (DMSO), form the major pool of organic sulfur in the marine environment. The production and transformation of these compounds comprise an important part of the sulfur cycle. DMS is readily oxidized in the atmosphere to form sulfate aerosols which are thought to be climatically important due to their ability to scat- 
ter sunlight and their role in the formation of cloud condensation nuclei. Both these processes increase the planetary albedo and exert a cooling influence on the climate. Charlson et al. (1987) have hypothesized that marine DMS production may act as a climate regulatory mechanism via a feedback loop involving surface ocean temperature, phytoplankton, DMS and sulfate aerosols. According to this hypothesis, warmer ocean temperatures resulting from global climate warming would stimulate processes leading to the production of DMS. The enhanced DMS release would lead to increased formation of sulfate aerosols and cloud condensation nuclei. Increased light scattering and cloud cover would exert a cooling effect on the climate, thereby counteracting the warming trend. The existence of this 'global thermostat' has not yet been confirmed, but there is evidence to support a relationship between DMS-derived sulfate aerosols and climatic events (Falkowski et al. 1992, Legrand 1997, Legrand et al. 1997, Clarke et al. 1998).

While phytoplankton are known to be the principal source of DMSP, bacteria are thought to provide the major mechanism for transforming DMSP to DMS in seawater (Kiene \& Service 1991, Gabric et al. 1993, Ledyard \& Dacey 1994, Wolfe 1996). The cleavage of DMSP to DMS and acrylate is accomplished enzymatically via DMSP-lyase which has been shown to exist in marine bacteria (Ledyard et al. 1993, de Souza \& Yoch 1995a, Yoch et al. 1997). There are also a few species of phytoplankton which are known to possess DMSPlyase (Stefels \& Dijkhuizen 1996, Steinke et al. 1998), and it is speculated that there may be others. The relative contribution of phytoplankton to marine DMS production is presently unknown, but may be significant in regions where DMSP-lyase-containing algal species are abundant. A second major mechanism of DMSP degradation by bacteria is demethylation, which does not produce DMS. Although some bacterial isolates expressing both pathways have been isolated (Gonzalez et al. 1999), the bacterial assemblage responsible for demethylation appears to be generally distinct from that responsible for DMSP cleavage (Visscher et al. 1992). The ratio of DMSP cleavage to demethylation is variable and is often expressed as a DMS production yield, or the rate of DMS production relative to the total loss rate of DMSP. DMSP cleavage is generally thought to be the less significant of the 2 processes, and DMS production yields measured in marine waters fall typically between 5 and $30 \%$ (Kiene \& Service 1991, Kiene 1992). There is some evidence that the yield may decrease as a phytoplankton bloom ages due to an increase in the relative importance of demethylation over DMSP cleavage (Kwint et al. 1996, van Duyl et al. 1998). In addition to bacterial DMS production, considerable bacterial consumption of DMS has been ob- served by various authors (Kiene \& Bates 1990, Kiene 1992, Kwint \& Kramer 1995, Kwint et al. 1996, Wolfe et al. 1999). These investigations have shown the importance of bacteria in regulating DMS production. However, studies of the dynamics and transformations of DMSP and DMS have usually been conducted in specific geographic regions (e.g. Bates et al. 1994, Matrai \& Vernet 1997) or specialized environments such as microbial mats (Jonkers et al. 1998). Little is known about the spatial and temporal variation of bacterial DMS production and consumption on oceanic scales. In particular, there is a lack of knowledge about the variation of this activity as a function of temperature. Although such a relationship might be inferred from the hypothesis of Charlson et al. (1987), few data exist to support this conjecture.

The present study had 2 major objectives. The first was to investigate DMS production and consumption processes (including potential DMS production rates) across a wide area of the temperate North Atlantic, extending between Nova Scotia, Bermuda and Newfoundland, in springtime. DMS production rates and rate constants were determined during short $(3 \mathrm{~h})$ incubations of surface seawater amended with a range of dissolved DMSP $\left(\mathrm{DMSP}_{\mathrm{d}}\right)$ concentrations (up to $3000 \mathrm{nM}$ ). The second major objective was to investigate the dynamics of DMSP-to-DMS transformations, including rates and percentage yields, under conditions simulating the first $2 \mathrm{~d}$ following the decline of a bloom. Long-term incubations (48 to $60 \mathrm{~h}$ ) were conducted in which DMS production and DMSP consumption were measured following the addition of a $100 \mathrm{nM}$ pulse of $\mathrm{DMSP}_{\mathrm{d}}$. This concentration falls within the upper range observed in open-ocean waters (Malin et al. 1993, Palmer Locarnini et al. 1998), and corresponds with $\mathrm{DMSP}_{\mathrm{d}}$ concentrations released following the decline of DMSP-producing phytoplankton blooms during mesocosm experiments (Kwint et al. 1996, Levasseur et al. 1996).

\section{MATERIALS AND METHODS}

The cruise track of May 1 to 17, 1998 (Fig. 1), was designed to traverse several water masses of different temperatures as defined by the biogeographic provinces of Longhurst (1995) (abbreviations in parentheses): Gulf Stream (GFST), North Atlantic Subtropical Gyre (NAST) commonly known as the Sargasso Sea, North Atlantic Drift (NADR) and the Northwest Continental Shelf (NWCS) including the Grand Banks. Surface-water temperatures encountered during this study ranged from 4 to $20^{\circ} \mathrm{C}$. Stations were occupied in each of the 4 biogeographic provinces. Incubations were also performed at 2 additional stations, near the 


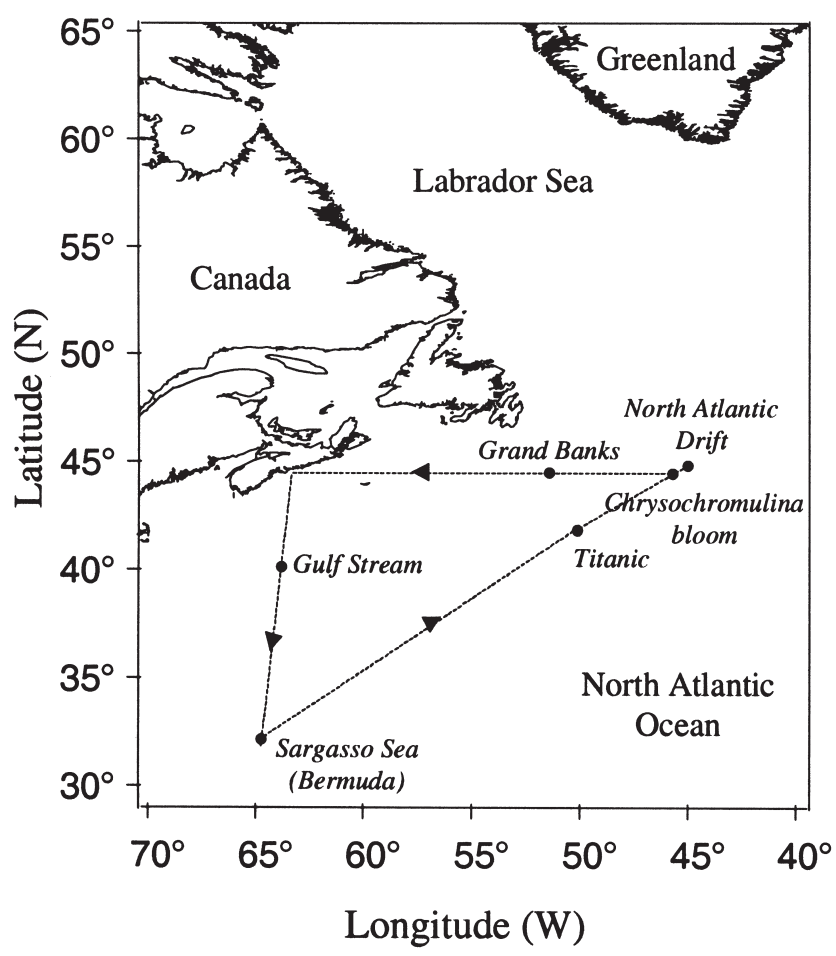

Fig. 1. Map of study area showing cruise track and locations of 6 sampling stations

Titanic wreck site and in a bloom of the prymnesiophyte Chrysochromulina sp. Not all types of experiments were performed at all stations. It should be noted that based on examination of the ship's continuous temperature log after the cruise, the Gulf Stream station was actually located slightly north of the stream itself. The Sargasso Sea fixed station was located at the Hydrostation S site of the Bermuda Atlantic Time Series (BATS) for which there is an existing time series of DMS data including 2 annual cycles (Dacey et al. 1998). At all stations, samples were collected with a rosette sampler equipped with 101 Niskin bottles and a CTD which simultaneously measured salinity, temperature, pressure and chlorophyll fluorescence. Chlorophyll a (chl a) was determined fluorometrically after filtration (Whatman GF/F) and extraction into 90\% acetone using the method of Parsons et al. (1984). Bacterial cell counts were performed on an epifluorescence microscope using formaldehyde-preserved samples filtered onto $0.2 \mu \mathrm{m}$ Nuclepore membranes and stained with DAPI using the method of Porter \& Feig (1980). Phytoplankton identification and enumeration was performed on formaldehyde-preserved samples using a settling column and inverted microscope.

All experiments were conducted using surface seawater collected by Niskin bottles at a depth of $<5 \mathrm{~m}$ and screened through $202 \mu \mathrm{m}$ Nitex mesh to remove large grazers. All pouring and mixing was performed gently to avoid bubble formation which could alter the concentration of DMS. As it was filtered, the water was transferred to $10 \mathrm{l}$ insulated containers from which it was dispensed into the incubation bottles. Incubation procedures were begun immediately following sample collection. The incubation bottles $(250 \mathrm{ml}$ brown polyethylene with screw caps) were cleaned by soaking in $10 \% \mathrm{HCl}$ overnight followed by rinsing with deionized water. They were rinsed once with seawater, filled completely to eliminate any headspace, and incubated in the dark at ambient surface temperature in a flowing seawater incubator. In bottles containing amendments of $\mathrm{DMSP}_{\mathrm{d}}$ and/or DMS consumption inhibitors (dimethyldisulfide and methyl butyl ether), the additions were made at the time of filling and the bottles gently inverted 3 times to mix the contents.

At each sampling point, 1 or 2 bottles of each treatment were mixed gently by slow inversion and then sampled for DMS and DMSP ${ }_{d}$. Samples were prepared by filtering $80 \mathrm{ml}$ from the incubation bottle through a $25 \mathrm{~mm}$ GF/F (Whatman) filter using gentle suction filtration (maximum vacuum $130 \mathrm{~mm} \mathrm{Hg}$ ). Although suction filtration may not be ideal, because of the potential for cell lysis on the filters, it was necessary to accommodate the high sample frequency (up to 12 bottles $\mathrm{h}^{-1}$ ). The initial measured $\mathrm{DMSP}_{\mathrm{d}}$ concentrations in the unamended bottles were elevated ca $50 \%$ over ambient levels during these experiments, possibly as a result of this effect. However, since the discrepancy probably arises during filtration, this should not affect the rates of DMSP consumption or DMS production in the incubations. DMS samples were prepared by carefully filling a $24 \mathrm{ml}$ serum vial with filtrate and immediately sealing the top with a butyl rubber septum and aluminum crimp. The vials were filled as completely as possible to minimize the remaining headspace. Separate tests (unpublished) indicated that there is no significant loss of DMS in samples sealed with butyl septa compared to those with Teflon septa, even following storage for several hours. DMS samples were analyzed as quickly as possible, usually within a few minutes of collection. For $\mathrm{DMSP}_{\mathrm{d}}$ samples, $23 \mathrm{ml}$ of filtrate was decanted into a vial containing $1 \mathrm{ml} \mathrm{KOH}$ solution $(10 \mathrm{~N})$. In the case of samples which contained very high concentrations of added $\mathrm{DMSP}_{\mathrm{d}}$ (500 nM and higher), only $1 \mathrm{ml}$ of filtrate was used, with the remaining volume made up of $22 \mathrm{ml}$ of deionized water plus $1 \mathrm{ml}$ of $10 \mathrm{~N} \mathrm{KOH}$. Although there is some potential loss of DMS while decanting the sample into a vial already containing $\mathrm{KOH}$, comparisons of this method with the injection of $\mathrm{KOH}$ into sealed sample vials revealed no significant difference in the measured $\mathrm{DMSP}_{\mathrm{d}}$ concentrations (unpubl. data). Furthermore, the manipulation is simpler and it eliminates the risk of leakage through the pierced septum during storage. 
DMSP samples were stored at $4{ }^{\circ} \mathrm{C}$ for at least $24 \mathrm{~h}$ to allow the solution to react, and were analyzed within at most 4 wk of collection.

Analyses were performed using a pair of purge-andtrap systems each coupled to a Varian 3400 gas chromatograph (GC) using a modified version of the method of Leck \& Bågander (1988) (see Cantin et al. 1996 for details of the method). One GC was fitted with a flame photometric detector (FPD), the other with a more sensitive pulsed-flame photometric detector (PFPD). The PFPD was used to analyze all the DMS samples and the more dilute DMSP samples. The FPD was used for the more concentrated DMSP samples. For the analysis of DMSP, the GCs were calibrated against a gravimetric standard of DMSP $\left(50 \mathrm{ng} \mathrm{ml}^{-1}\right.$ in distilled water) prepared in $10 \mathrm{ml}$ crimp vials containing $0.4 \mathrm{ml} 10 \mathrm{~N} \mathrm{KOH}$. For the analysis of DMS samples, the GC was calibrated against microlitre injections of He containing approximately $17 \mathrm{ng} \mathrm{ml}^{-1}$ of DMS. This was prepared using a permeation tube apparatus (KinTek). The analytical method has a precision of ca $10 \%$ and a minimum quantification limit for both DMS and DMSP $_{\mathrm{d}}$ of ca $0.08 \mathrm{nM}$.

Three types of experiments were performed:

Short-term incubations - kinetic rate determinations. These experiments were based on the methods of Ledyard (1993) and Schultes et al. (2000). Briefly, 28 water samples $(250 \mathrm{ml})$ were incubated for up to $3 \mathrm{~h}$ with a series of added $\mathrm{DMSP}_{\mathrm{d}}$ concentrations $(0,50$, 100, 500, 1000, 2000 and $3000 \mathrm{nM}$ ). At Time 0 and after each hour, 1 bottle at each $\mathrm{DMSP}_{\mathrm{d}}$ concentration was filtered and analyzed for DMS and $\mathrm{DMSP}_{\mathrm{d}}$. For each initial $\mathrm{DMSP}_{\mathrm{d}}$ concentration, the average DMS production rate $\left(\mathrm{nmol} \mathrm{l}^{-1} \mathrm{~h}^{-1}\right.$ ) over the $3 \mathrm{~h}$ experiment was determined from the linear regression of DMS concentration versus time. A rate constant $(k)$ was calculated for each experiment by plotting the DMS production rate vs initial $\mathrm{DMSP}_{\mathrm{d}}$ concentration and determining the slope. Since the experiments are conducted using the natural microbial assemblage (including phytoplankton), and rely on additions of $\mathrm{DMSP}_{\mathrm{d}}$, the measured rates are potentials which apply to the entire assemblage, not simply to bacteria. The rate constant is thus a 'community potential' rate constant (hereafter abbreviated $k_{\text {pot }}$ ) which is effectively an index of the potential for DMS production by the microbial community following a pulse of $\mathrm{DMSP}_{\mathrm{d}}$. This experiment was performed at 5 stations: Gulf Stream, Sargasso Sea, Titanic, North Atlantic Drift and Grand Banks.

Long-term incubations. At 4 stations (Gulf Stream, Sargasso Sea, North Atlantic Drift and Grand Banks), the incubation procedures were extended to allow determination of the dynamics of DMSP and DMS over longer timescales, including whether the DMS production rates observed in short-term incubations could be sustained for more than a few hours. The control (0 nM added $\mathrm{DMSP}_{\mathrm{d}}$ ) and $100 \mathrm{nM}$ added $\mathrm{DMSP}_{\mathrm{d}}$ treatments were extended to include duplicate samples at 6 to $12 \mathrm{~h}$ intervals over 48 to $60 \mathrm{~h}$. The principal objective was to determine both the endogenous rates of $\mathrm{DMSP}_{\mathrm{d}}$ consumption and DMS production over $\geq 48 \mathrm{~h}$ as well as the potential rates following a $100 \mathrm{nM}$ pulse of $\mathrm{DMSP}_{\mathrm{d}}$. Another objective of the long-term experiments was to measure bacterial DMS consumption rates using chemical inhibitors to prevent the bacterial consumption of DMS. By measuring the rate of DMS production with and without inhibitors, the rate of bacterial DMS consumption can be calculated from the difference. This method has been employed by other authors using a variety of chemical inhibitors (Kiene 1990, 1992, Visscher \& Taylor 1993, Wolfe et al. 1999). In this study, dimethyldisulfide (DMDS) and methyl butyl ether (MBE) were used as specific inhibitors of bacterial DMS consumption (Visscher \& Taylor 1993, Wolfe \& Kiene 1993). They were added to the incubation bottles at final concentrations of $200 \mathrm{nM}$ and $30 \mu \mathrm{M}$ for DMDS and MBE, respectively. The inhibitors were added to bottles both with and without the $100 \mathrm{nM} \mathrm{DMSP}_{\mathrm{d}}$ amendment. Although the precise mechanism of inhibition has not been described, isotopic tracer studies using ${ }^{35} \mathrm{~S}$ suggest that DMDS does not inhibit DMSP demethylation (R. P. Kiene pers. comm.), and therefore should not interfere with measurements of DMSP consumption. Measurements were taken at the same intervals as for the control and $100 \mathrm{nM} \mathrm{DMSP}_{\mathrm{d}}$ treatments. Because of limitations in the rate of sample processing and analysis, a maximum of 6 different treatments could be used in each experiment. At all stations these included a control with no additional $\mathrm{DMSP}_{\mathrm{d}}$ and a $100 \mathrm{nM} \mathrm{DMSP}$ treatment. Thus, for a typical long-term experiment the 6 treatments were: (1) control (no addition); (2) $100 \mathrm{nM}$ $\mathrm{DMSP}_{\mathrm{d}}$ (3) control + DMDS; (4) $100 \mathrm{nM} \mathrm{DMSP}_{\mathrm{d}}+$ DMDS $_{i}$ (5) control + MBE; (6) $100 \mathrm{nM} \mathrm{DMSP}{ }_{\mathrm{d}}+\mathrm{MBE}$. With duplicate bottles for each treatment, 12 bottles were sampled at each time point for a total of 24 samples (12 each of DMS and DMSP ${ }_{\mathrm{d}}$ ). Note that the MBE treatments were omitted at the Sargasso Sea station.

DMS consumption. To verify the results of the inhibitor experiments, a second method of measuring DMS consumption was developed employing direct additions of DMS to seawater. A gas stream (DMS in $\mathrm{He})$ at a concentration of approximately $17 \mathrm{ng}$ DMS $\mathrm{ml}^{-1}$ was prepared using a permeation tube. One hundred $\mathrm{ml}$ of this gas was injected into a 11 Tedlar gas sampling bag (Chromatographic Specialties) containing approximately $600 \mathrm{ml}$ of gravity-filtered surface seawater ( $2 \mu \mathrm{m}$ GMF glass-fibre filter, Whatman) to yield a final concentration of approximately $50 \mathrm{nM}$ DMS. The bag was agitated gently and kept in the 
dark at room temperature for approximately $1 \mathrm{~h}$ to allow it to reach equilibrium. The water was then transferred via syringe into ten, $30 \mathrm{ml}$ crimp-sealed vials and incubated in the dark at ambient surface seawater temperature. By pre-filtering the seawater through a $2 \mu \mathrm{m}$ filter, the intention was to remove most of the phytoplankton while allowing most of the freeliving bacteria to remain in the sample. This method was employed to allow direct injection of the samples into the purge/trap apparatus without the risk of introducing phytoplankton cells and detritus which could contaminate the apparatus with DMSP. The possible limitation of this approach is that any bacteria associated with particles or phytoplankton cells which may have been present in the sample were probably removed during the filtration step. It is not known whether this could affect the measured DMS consumption rates. Duplicate bottles were analyzed for DMS concentration at $t=0$ and at approximately $12 \mathrm{~h}$ intervals thereafter for $48 \mathrm{~h}$. A parallel series of bottles containing only filtered seawater (no added DMS) were analyzed as a control. Experiments of this type were performed in the Sargasso Sea, the North Atlantic Drift and the Chrysochromulina sp. bloom station.

\section{RESULTS}

\section{Characteristics of the sampling stations}

Table 1 describes the 6 stations where experiments were conducted. Water salinity, temperature, and the in situ concentrations of chl $a$, bacteria, DMS, DMSP and particulate DMSP (DMSP $)$ are given as well as the dominant phytoplankton species. The Chrysochromulina sp. bloom station stands out as having the highest concentrations of DMS, DMSP $\mathrm{p}$ and bacterial cells. At this station, the population of Chrysochromulina sp. in the surface water was approximately $4 \times 10^{5}$ cells $\mathrm{l}^{-1}$. By comparison the other stations had much lower phytoplankton populations. The Gulf Stream station had a mixed population of flagellates (ca $1.5 \times 10^{5}$ cells $\mathrm{l}^{-1}$ ). The Sargasso Sea and North Atlantic Drift stations were dominated by the naked dinoflagellates Gymno-

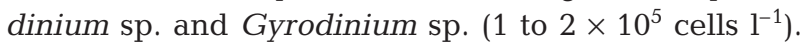
The Titanic station was dominated by a sparse population of Chaetoceros sp. $\left(7 \times 10^{4}\right.$ cells $\left.1^{-1}\right)$ while the Grand Banks displayed a mixed population of cryptophytes $\left(1 \times 10^{5}\right.$ cells $\left.\mathrm{l}^{-1}\right)$.

\section{Short-term experiments}

Fig. 2A shows the results of a typical short-term experiment, in this case at the Sargasso Sea station. Production of DMS proceeded in a linear fashion for at least $3 \mathrm{~h}$ after the addition of $\mathrm{DMSP}_{\mathrm{d}}$. The slopes of the DMS curves (the potential DMS production rates) increase in direct proportion to the concentration of added $\mathrm{DMSP}_{\mathrm{d}}$, although only at $\mathrm{DMSP}_{\mathrm{d}}$ concentrations of $500 \mathrm{nM}$ or more were the slopes significantly different from zero (Student's $t$-test, $\mathrm{p} \leq 0.05$ ). Similar results were obtained at the other 4 stations. Fig. 2B shows the DMSP $_{d}$ concentrations during the course of a typical short-term experiment. The slopes were not significantly different from zero, and hence show no clear

Table 1. Characteristics of sampling stations showing oceanographic province (GFST: Gulf Stream; NAST: North Atlantic Subtropical Gyre; NADR: North Atlantic Drift; NWCS: Northwest Continental Shelf [as defined by Longhurst 1995]); salinity, water temperature, incubation temperature, and in situ concentrations of chlorophyll $a$, bacteria, DMS, DMSP $\mathrm{d}_{\mathrm{d}}, \mathrm{DMSP}_{\mathrm{p}}$ and dominant phytoplankton taxa. All samples were taken at a depth of $<5 \mathrm{~m}$. Bottom row: experiments performed at each station (ST: shortterm; LT: long term; C: DMS consumption)

\begin{tabular}{|c|c|c|c|c|c|c|}
\hline & Gulf Stream & $\begin{array}{l}\text { Sargasso } \\
\text { Sea }\end{array}$ & $\begin{array}{l}\text { North Atlantic } \\
\text { Drift }\end{array}$ & Grand Banks & Titanic & $\begin{array}{l}\text { Chrysochro- } \\
\text { mulina bloom }\end{array}$ \\
\hline Oceanographic province & GFST & NAST & NADR & NWCS & NWCS & NADR \\
\hline Salinity & 35.9 & 36.5 & 35.9 & 32.9 & 32.7 & 35.8 \\
\hline Surface temp. $\left({ }^{\circ} \mathrm{C}\right)$ & 18.2 & 20.2 & 15.3 & 3.1 & 4.2 & 14.4 \\
\hline Incubation temp. $\left({ }^{\circ} \mathrm{C}\right)$ & 19 & 20 & 16 & 6 & 7 & 14.5 \\
\hline $\mathrm{Chl} a\left(\mu \mathrm{g} \mathrm{l}^{-1}\right)$ & 0.85 & 0.10 & 0.62 & 0.26 & 0.25 & 0.52 \\
\hline Bacteria $\left(10^{9}\right.$ cells $\left.1^{-1}\right)$ & 0.15 & 0.22 & 0.34 & 0.58 & 0.22 & 1.6 \\
\hline In situ DMS (nM) & 0.3 & 2.2 & 2.3 & 0.3 & 1.0 & 4.3 \\
\hline In situ $\operatorname{DMSP}_{\mathrm{p}}(\mathrm{nM})$ & 11.7 & 21.7 & 30.2 & 39.4 & 8.5 & 78.9 \\
\hline In situ $\mathrm{DMSP}_{\mathrm{d}}(\mathrm{nM})$ & 3.2 & 5.4 & 12.4 & 6.4 & 3.1 & 7.7 \\
\hline $\begin{array}{l}\text { Dominant } \\
\text { phytoplankton }\end{array}$ & Flagellates & $\begin{array}{l}\text { Gymnodinium } \\
\text { sp. and Gyro- } \\
\text { dinium sp. }\end{array}$ & $\begin{array}{l}\text { Gymnodinium } \\
\text { sp. and Gyro- } \\
\text { dinium sp. }\end{array}$ & $\begin{array}{c}\text { Mixed } \\
\text { Cryptophyceae }\end{array}$ & $\begin{array}{l}\text { Chaetoceros } \\
\text { sp. }\end{array}$ & $\begin{array}{l}\text { Chrysochro- } \\
\text { mulina sp. }\end{array}$ \\
\hline Experiments & ST, LT & $\mathrm{ST}, \mathrm{LT}, \mathrm{C}$ & $\mathrm{ST}, \mathrm{LT}, \mathrm{C}$ & $\mathrm{ST}, \mathrm{LT}$ & ST & $\mathrm{C}$ \\
\hline
\end{tabular}



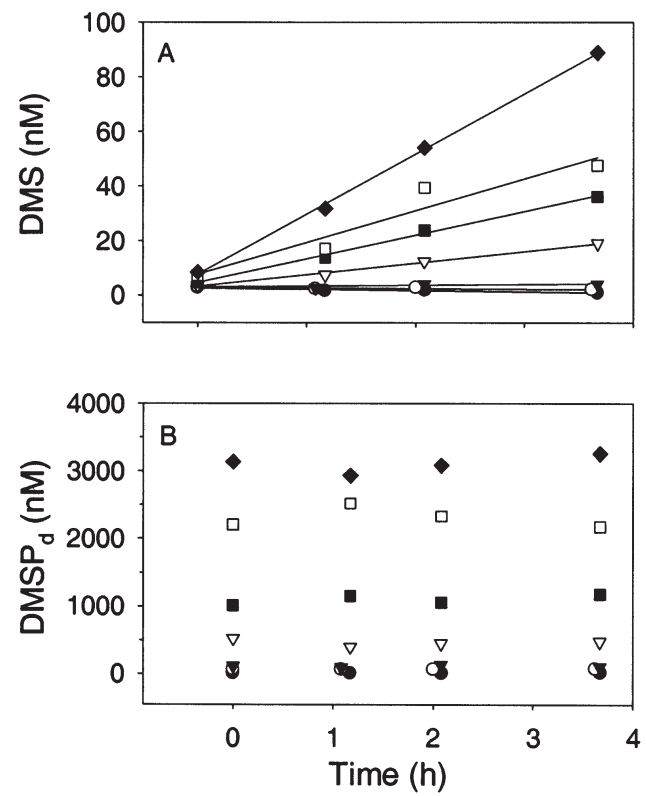

Fig. 2. Results of typical short-term incubation (kinetics experiment) at Sargasso Sea station. (A) Production of DMS (continuous lines indicate least-squares fit); (B) changes in $\mathrm{DMSP}_{\mathrm{d}}$ following amendment with $\mathrm{DMSP}_{\mathrm{d}}$ at 6 different concentrations. DMSP $\mathrm{d}_{\mathrm{d}}$ amendment key: $(\bullet) 0 \mathrm{nM}_{i}(\mathrm{O}) 50 \mathrm{nM}$;

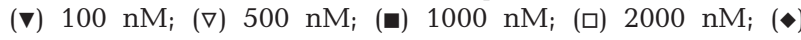
$3000 \mathrm{nM}$

trend over the $3 \mathrm{~h}$ experiment. $\mathrm{DMSP}_{\mathrm{d}}$ will be discussed in more detail in the context of the long-term experiments where the changes were significant and trends can be more easily discerned.

Using the slopes of the DMS curves from Fig. 2A, a kinetic curve can be constructed by plotting the potential DMS production rates against the concentrations of added $\mathrm{DMSP}_{\mathrm{d}}$. Fig. 3 shows such curves for 5 stations. Note that different vertical scales are used in each graph to provide the best resolution. While the $95 \%$ confidence interval bars on the rate estimates are in some cases large, and some of the rates are not statistically significant, it is important to remember that each rate determination is based on 4 independent samples, each incubated for a different interval. Notwithstanding that some rate determinations were not significant, all points fall very close to the leastsquares line and have therefore been included in the regression to determine the potential rate constant $k_{\text {pot }}$ (simply the slope of the line). No evidence of saturation was observed over the concentration range tested. In Fig. $4, k_{\text {pot }}$ is plotted relative to 4 variables which might be expected to influence potential DMS production: incubation temperature, chl a (as an index of phytoplankton standing stock), $\mathrm{DMSP}_{\mathrm{p}}$ (an index of the standing stock of DMSP-producing phytoplankton) and bacterial counts. Fig. 4A shows the relation-

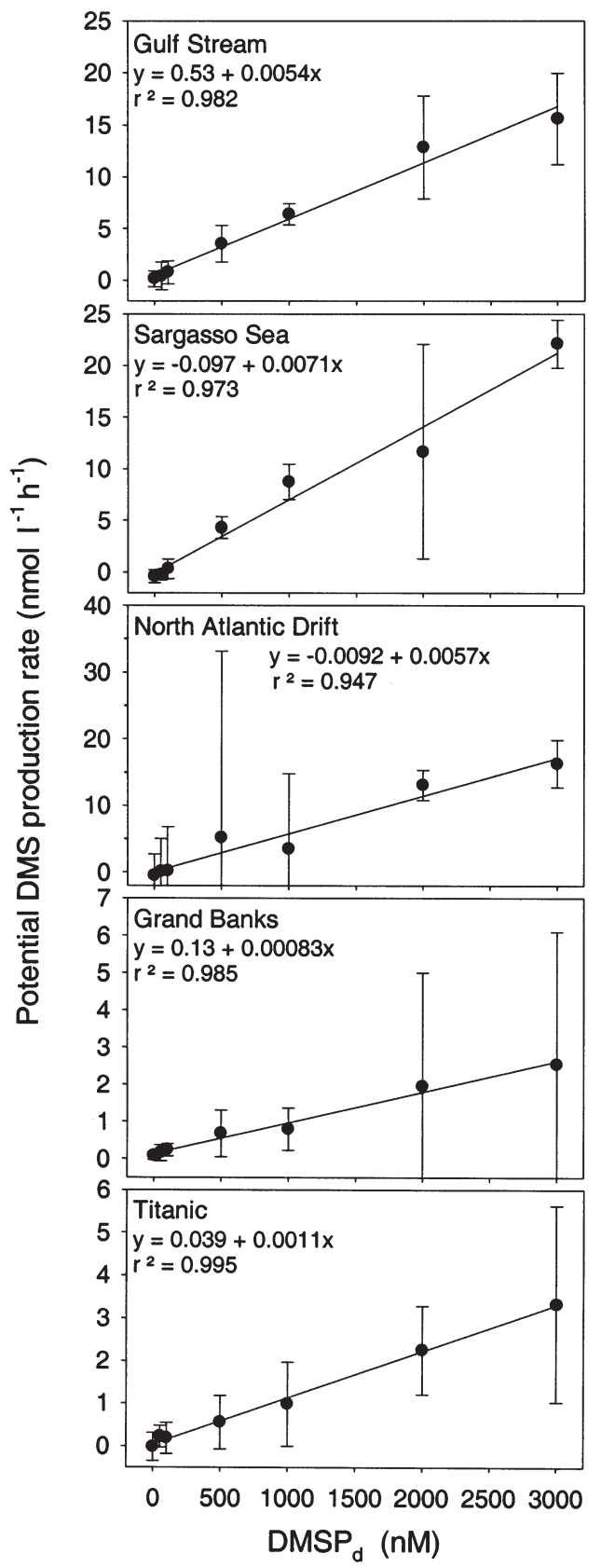

Fig. 3. Kinetic plots from short-term incubations at 5 stations. Potential DMS production rate versus initial DMSP ${ }_{d}$ concentration. Error bars: 95\% confidence intervals of each rate determination; continuous lines: least-squares linear fit

ship between $k_{\text {pot }}$ and incubation temperature. The data show that warmer temperatures were associated with higher rate constants in an apparently linear relationship. However, there is a large gap in the data between 7 and $16^{\circ} \mathrm{C}$, so a truly linear trend is not certain. Fig. 4B, C \& D reveal no significant relationships between $k_{\text {pot }}$ and chl $a_{1}$ DMSP $_{\mathrm{p}}$ or bacterial cell counts. 


\section{Long-term incubations}

Fig. 5A shows DMSP ${ }_{\mathrm{d}}$ concentrations during the $60 \mathrm{~h}$ incubation at the Sargasso Sea station. For clarity, only the control and $100 \mathrm{nM} \mathrm{DMSP}_{\mathrm{d}}$ treatments are shown.
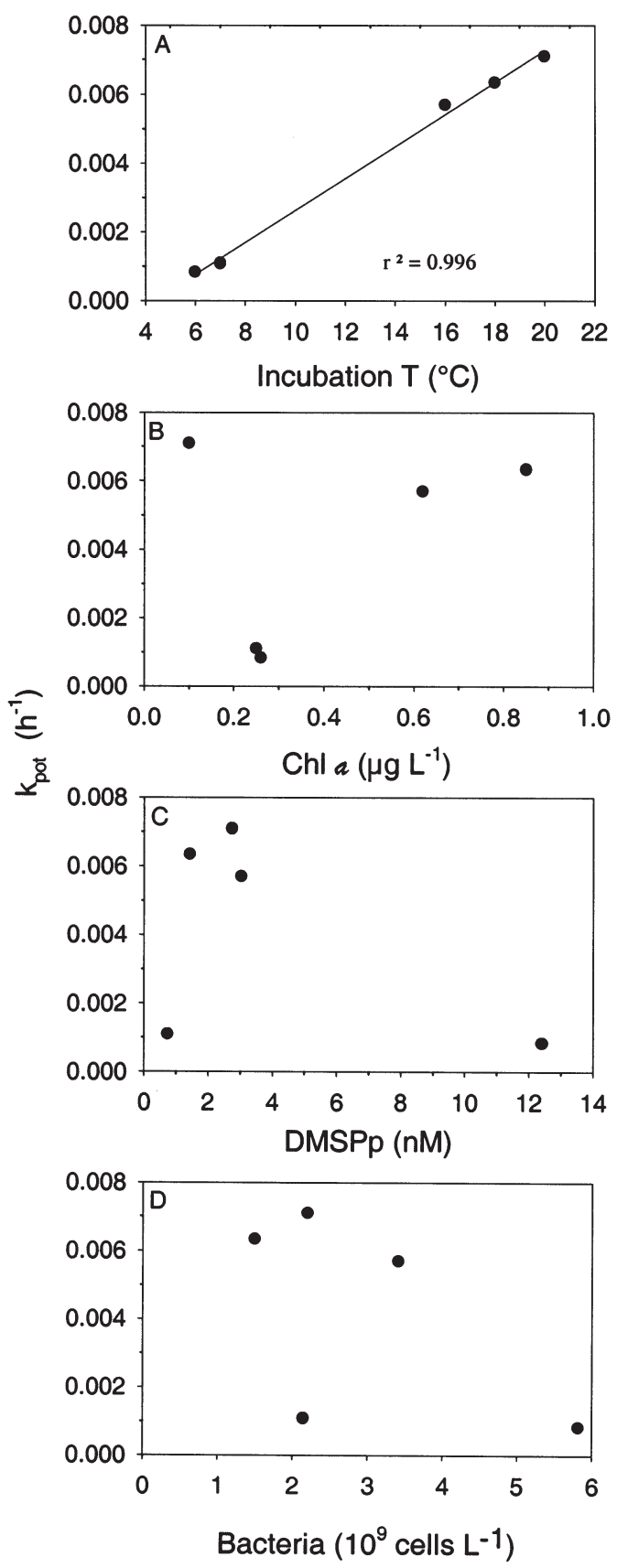

Fig. 4. Results of kinetic experiments at 5 stations showing relationships between potential rate constants $\left(k_{\text {pot }}\right)$ and other oceanographic variables. (A) Incubation temperature; (B) chlorophyll a concentration; (C) DMSP $_{p}$ concentration, (D) bacterial abundance
The corresponding inhibitor treatments followed very similar patterns. In both the control and the $100 \mathrm{nM}$ treatment, $\mathrm{DMSP}_{\mathrm{d}}$ underwent little net change in the initial $12 \mathrm{~h}$, although the concentrations appeared to fluctuate about the mean. At some stations (the Gulf Stream and the control bottles at Sargasso Sea and the Grand Banks), DMSP ${ }_{d}$ actually increased during the initial 12 to $24 \mathrm{~h}$ before declining. Possible reasons for these variations are discussed below. After this initial increase, net $\mathrm{DMSP}_{d}$ consumption proceeded rapidly and the $\mathrm{DMSP}_{\mathrm{d}}$ concentrations declined quickly over the remainder of the experiment. At none of the stations was the added $\mathrm{DMSP}_{\mathrm{d}}$ completely exhausted by the end of the incubation. The post-lag rate of $\mathrm{DMSP}_{\mathrm{d}}$ consumption was initially high and decreased as the concentrations diminished. Fig. 6A shows the average post-lag $\mathrm{DMSP}_{\mathrm{d}}$ consumption rates for the controls and $100 \mathrm{nM}$ added $\mathrm{DMSP}_{\mathrm{d}}$ treatments at all 4 stations. The consumption rate in the controls was highest in the North Atlantic Drift $\left(1 \mathrm{nmol} \mathrm{l}^{-1} \mathrm{~h}^{-1}\right)$ and much lower at the other 3 stations ( 0 to $0.2 \mathrm{nmol} \mathrm{l}^{-1} \mathrm{~h}^{-1}$ ). In the $\mathrm{DMSP}_{\mathrm{d}}$-amended treatments, the consumption rates also varied greatly, and again showed the highest rate in the North Atlantic Drift $\left(2.3 \mathrm{nmol}^{-1} \mathrm{~h}^{-1}\right)$ and the lowest rates on the Grand Banks $\left(1.3 \mathrm{nmol} \mathrm{l}^{-1} \mathrm{~h}^{-1}\right)$.

Fig. 5B shows the DMS production curves for the control and $\mathrm{DMSP}_{\mathrm{d}}$-amended $(100 \mathrm{nM})$ bottles at the Sargasso Sea station. As with the $\mathrm{DMSP}_{\mathrm{d}}$ curves, there
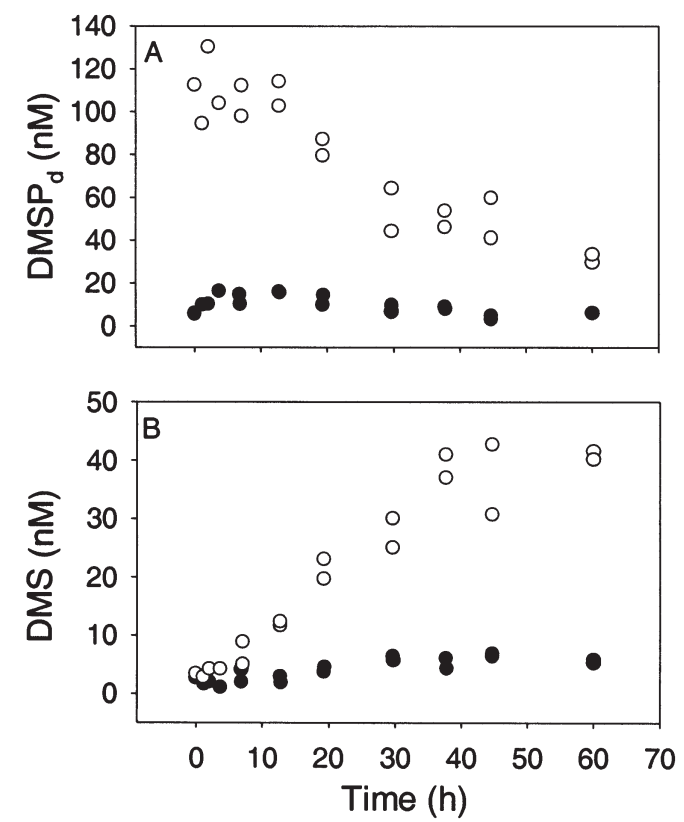

Fig. 5. Results of long-term incubation (Sargasso Sea station): (A) $\mathrm{DMSP}_{\mathrm{d}}$ concentration; (B) DMS concentration. (•) control; (O) $100 \mathrm{nM}$ added $\mathrm{DMSP}_{\mathrm{d}}$ 
appeared to be a slight lag in DMS production for the first few hours of the incubation. However, this lag was observed only at the Sargasso Sea station and may not be a general feature of such incubations. Following this lag, DMS production proceeded in a linear fashion for approximately $40 \mathrm{~h}$ after the $\mathrm{DMSP}_{\mathrm{d}}$ addition. DMS accumulated steadily in the control bottles, indicating that there was a small net production of DMS in unamended samples. DMS production in the $\mathrm{DMSP}_{\mathrm{d}}$ amended samples was much faster than in the controls, and by the end of the experiment the DMS concentration had stabilized, indicating that net DMS production had ceased. This plateau was observed at all stations except the Grand Banks. Average DMS production rates (over $40 \mathrm{~h}$ ) for the controls and $100 \mathrm{nM}$ added $\mathrm{DMSP}_{\mathrm{d}}$ treatments are shown in Fig. 6B. The error bars indicate the $95 \%$ confidence interval of each rate.

In the long-term incubations with $100 \mathrm{nM}$ added $\mathrm{DMSP}_{\mathrm{d}}$, the highest potential rates of both $\mathrm{DMSP}_{\mathrm{d}}$ consumption and DMS production were observed in the North Atlantic Drift while the lowest rates were observed on the Grand Banks (Fig. 6). The rates measured in the DMDS and MBE treatments are not shown, but no significant differences were seen between treatments which contained inhibitors and those which did not $(\mathrm{p}>0.05)$. This indicates that DMS con-

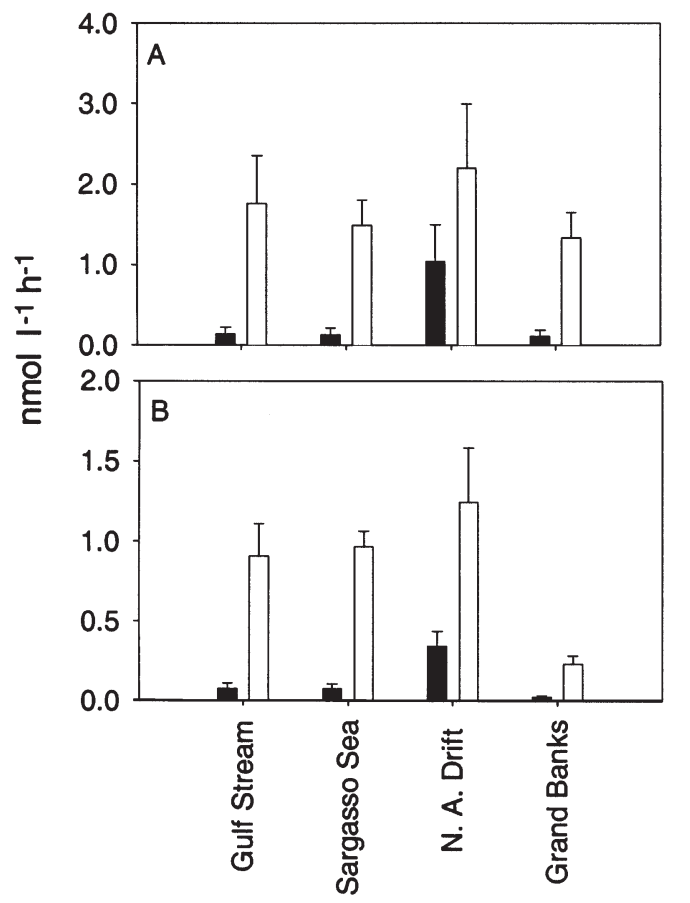

Fig. 6. Results of long-term incubations at 4 stations. (A) Net $\mathrm{DMSP}_{\mathrm{d}}$ consumption rate; (B) net DMS production rate. Black bars: controls; open bars: $100 \mathrm{nM}$ added $\mathrm{DMSP}_{\mathrm{d}}$ treatments; error bars: $95 \%$ confidence interval of each rate $(11 \leq n \leq 18)$ sumption was undetectably low relative to the precision of the analyses. The implication of this is that the net DMS production rates measured here may in fact be insignificantly different from the gross production rates. Losses due to photoxidation are excluded, since the incubations were performed in the dark.

\section{DMS consumption experiments}

The DMS consumption experiments using the direct addition method were performed at 3 stations: Sargasso Sea, North Atlantic Drift and Chrysochromulina sp. bloom (Fig. 7A). The results indicate that significant bacterial consumption of DMS was observed only at the Chrysochromulina sp. bloom station. Furthermore, rapid DMS consumption was apparent only in the sample with added DMS (60 nM). The net consumption rate in the control bottles was near zero at all 3 stations. Fig. 7B shows bacterial counts for all the stations in this study. The Chrysochromulina sp. bloom station displayed an exceptionally high bacterial abundance, which was accompanied by a high DMS consumption rate.

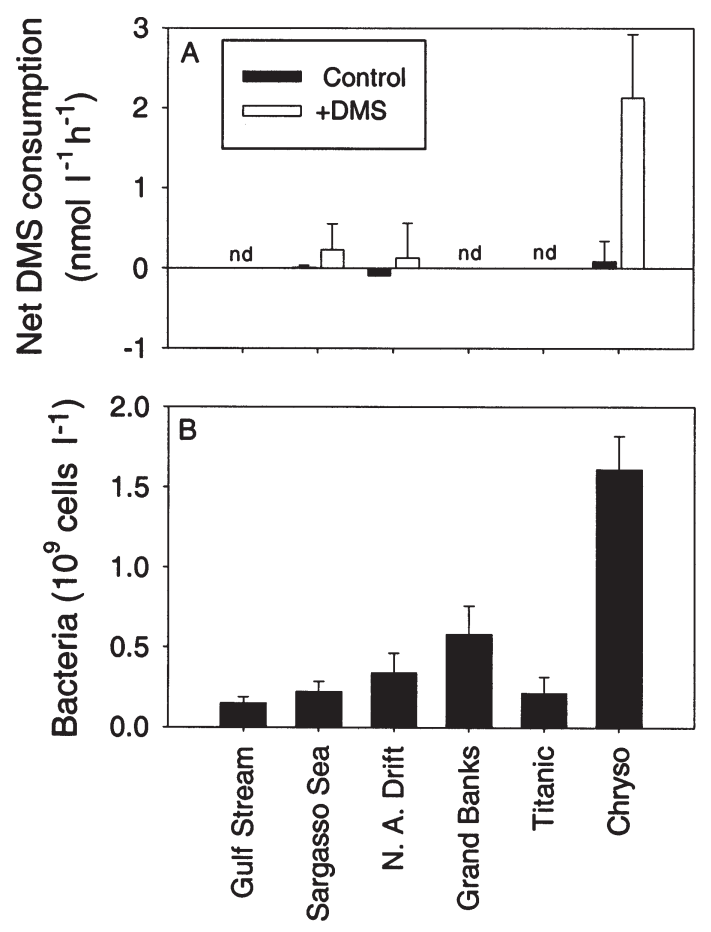

Fig. 7. (A) DMS consumption rate in unamended and amended (60 nM DMS) $2 \mu \mathrm{m}$ filtered seawater samples; error bars: $95 \%$ confidence interval of each rate $(n=10)$. nd: no data. (B) Bacterial abundance for all stations; error bars: SDs of mean of 20 microscope fields. Chryso: Chrysochromulina sp. 


\section{DISCUSSION}

\section{Short-term kinetics of DMS production}

Since all the rates and rate constants determined in these experiments are based upon amendments of $\mathrm{DMSP}_{\mathrm{d}}$, they must be regarded as potential rates, and might not reflect the actual in situ rates in unamended seawater. However, the striking linearity of the kinetic plots, even at amendments of 50 and 100 nM DMSP, suggests that the relationships found here are applicable to lower (and possibly higher) concentrations. At all stations, net production of DMS by the microbial community was clearly dependent upon the concentration of added $\mathrm{DMSP}_{\mathrm{d}}$, with apparently linear (substratelimited) kinetics. None of the 5 experiments showed any signs of saturation at high $\mathrm{DMSP}_{\mathrm{d}}$ concentrations. This is consistent with results from pure bacterial cultures which are known to have half-saturation constants $\left(K_{\mathrm{m}}\right)$ for DMSP cleavage in the micromolar range (Ledyard \& Dacey 1994, de Souza \& Yoch 1995b). Purified DMSP-lyase from the bacterium Alcaligenes sp. has a $K_{\mathrm{m}}=2 \mathrm{mM}$ (de Souza \& Yoch 1995a). Thus it is clear that DMSP cleavage activity in marine bacteria remains unsaturated at concentrations which far exceed the normal ambient levels of $\mathrm{DMSP}_{\mathrm{d}}$ in the water column (global mean monthly average $\mathrm{DMSP}_{\mathrm{d}}=$ $18.1 \mathrm{nM}, \mathrm{SD}=32.4 \mathrm{nM}$ : Kettle et al. 1999). Ledyard \& Dacey (1994) speculated that this might indicate that bacteria are adapted to high $\mathrm{DMSP}_{\mathrm{d}}$ concentrations such as might be found in close association with cells and particles. This is supported by the observation by Cantin et al. (1999) that high potential rates of DMS production are associated with the particulate fraction in natural seawater samples. Microenvironments of high dissolved organic carbon concentration are postulated to exist around phytoplankton cells and in aggregates of marine snow (Azam \& Ammerman 1984, Mitchell et al. 1985, Bowen et al. 1993, Blackburn et al. 1998). Although the conjecture that bacteria can effectively exploit such microenvironments is based more on modelling than direct observation (Bowen et al. 1993, Blackburn et al. 1997), some authors have speculated that such behaviour could explain the very high $K_{\mathrm{m}}$ values which have been observed for the bacterial uptake of various organic compounds, including glucose (Azam \& Hodson 1981, Nissen et al. 1984). The possibility also exists that non-saturating kinetics could result from a low-affinity membrane-transport system, perhaps not even specific to $\mathrm{DMSP}_{\mathrm{d}}$, or indeed from simple diffusive transport across the cell membrane as suggested by Logan \& Fleury (1993). However, there have been some reported observations of saturated DMS production kinetics in seawater under certain conditions (Ledyard \& Dacey 1996, Scarratt et al. 2000), which supports the existence of an enzymatic mechanism. Regardless of the actual mechanism involved, the unsaturability of DMSP cleavage at the DMSP $_{\mathrm{d}}$ concentrations typically measured in bulk seawater means that the potential DMS production following a phytoplankton bloom is limited only by the amount of $\mathrm{DMSP}_{\mathrm{d}}$ released.

The observation of non-saturating kinetics across 4 different water masses and a wide range of temperatures indicates that this may be a general response in marine waters. However, there is evidence that bacterial DMSP cleavage can be saturated under some conditions. For example, in an earlier field study, Ledyard \& Dacey (1996) found linear DMSP cleavage kinetics with no detectable saturation in seawater samples collected in the Sargasso Sea, but reported saturation in samples from coastal waters $\left(28 \mathrm{nM} \leq K_{\mathrm{m} \text { (app) }} \leq 575 \mathrm{nM}\right.$, depending on the season). They also noted possible seasonal differences in the Sargasso Sea, with saturable kinetics observed in winter $\left(K_{\mathrm{m}(\mathrm{app})}=20 \mathrm{nM}\right)$, but not in autumn or spring. Such variations in DMS production kinetics could be dependent on the species composition of the microbial assemblage found at specific times of the year. It is known that certain taxa of marine bacteria possess DMSP-lyase activity while others do not (Ledyard et al. 1993), and that the composition of bacterial assemblages varies with bloom age and grazing pressure among other factors (Šimek et al. 1997, Kuennis 1998). The presence or absence of phytoplankton containing DMSP-lyase is another potentially important factor. The $K_{\mathrm{m}(\mathrm{app})}$ of the community is likely to be influenced by the presence of algal DMSP-lyases, and might vary with the species of phytoplankton involved.

The data from the 5 short-term experiments show a strong relationship between $k_{\text {pot }}$ and the incubation temperature. Since $k_{\text {pot }}$ is an index of the potential for DMS production by the planktonic community, this could represent either the direct effect of temperature on microbial activity or an indirect effect wherein water masses with different characteristics contain different populations of bacteria and phytoplankton. Such mechanisms, if real, could help support the 'global thermostat' hypothesis of Charlson et al. (1987). Changes in global ocean temperature which affect microbial populations could alter the distribution and rates of DMS production in surface waters. However, the 5 experiments shown here reveal no direct relationship between $k_{\text {pot }}$ and phytoplankton biomass, measured as either chl a or $\mathrm{DMSP}_{\mathrm{p}}$. This further reinforces the conclusion that marine waters have a large potential for DMS production, even in areas where in situ DMS and DMSP production are normally low. The observation that the potential rate constant shows no direct relationship with bacterial abundance could 
be related to 2 factors. Firstly, it is likely that only a minority of the bacterial population is actively producing DMS. For example, Visscher et al. (1992) found in the Caribbean Sea that DMSP-utilizing bacteria comprise only $10 \%$ of the total bacterial population, and only a subset of those produce DMS. Secondly, if algal DMSP-lyases make a significant contribution to the overall DMSP-lyase activity in seawater, then the potential rate constant will not necessarily be correlated with bacterial biomass.

\section{Long-term changes in DMS and $\mathrm{DMSP}_{d}$}

The 4 long-term experiments allowed the resolution of changes in the relative concentrations of DMS and $\mathrm{DMSP}_{\mathrm{d}}$, and can provide some insight into the timescale and efficiency of the cleavage mechanism.

After an initial period of stable or increasing concentrations, $\mathrm{DMSP}_{\mathrm{d}}$ declined quickly and at some stations was almost completely depleted by the end of the experiment. As the $\mathrm{DMSP}_{\mathrm{d}}$ concentration diminished, the consumption rate also declined, indicating that this rate is concentration-dependent. Note that this consumption is the net decrease in $\mathrm{DMSP}_{\mathrm{d}}$, and therefore includes changes resulting from all microbial uptake (cleavage, demethylation, microbial oxidation, intracellular storage, etc.) as well as production of $\mathrm{DMSP}_{\mathrm{d}}$ by the phytoplankton in the sample. The initial increase in $\mathrm{DMSP}_{\mathrm{d}}$ concentration in the first few hours was observed at 3 stations (Gulf Stream, Sargasso Sea and Grand Banks), both in controls and in $\mathrm{DMSP}_{\mathrm{d}}$-amended bottles. In 1 case (Sargasso Sea), an accompanying lag in DMS production was also observed. It is possible that an acclimation period of several hours is needed before the microbial community can begin to use a new source of $\mathrm{DMSP}_{\mathrm{d}}$. However, this lag period was not observed in all long-term incubations, nor was it observed in the higher-concentration treatments $\left(\mathrm{DMSP}_{\mathrm{d}} \geq 500 \mathrm{nM}\right)$ of the short-term incubations. An alternative explanation is that the initial variations in $\mathrm{DMSP}_{d}$ concentration could be the result of phytoplankton cell lysis or leakage immediately following the start of the incubation. These processes could have been induced either as the result of stress caused by handling the samples or as a result of grazing by microzooplankton which would have been present in the samples. They may also represent an artifact introduced during the vacuum filtration which could liberate DMSP from cells. However, the generally good repeatability of the duplicate measurements later in the incubations suggests this was probably not the case. None of these possibilities can be confirmed in the absence of particulate DMSP determinations and cell counts or chlorophyll measurements during the incubations.
With the possible exception of the Sargasso Sea station, where the initial lag period was observed, DMS production proceeded in a linear fashion for approximately $40 \mathrm{~h}$ following the initial $100 \mathrm{nM}$ pulse of $\mathrm{DMSP}_{\mathrm{d}}$. This suggests that no significant changes occurred in the bacterial population during this time period which affected its ability to utilize $\mathrm{DMSP}_{\mathrm{d}}$ or DMS. Specifically, enzyme induction does not appear to be a factor. At the Grand Banks station, $\mathrm{DMSP}_{\mathrm{d}}$ did not become greatly depleted, and DMS production, although slow, continued until the end of the incubation. However, at the other 3 stations (Gulf Stream, Sargasso Sea and North Atlantic Drift) the added DMSP $_{d}$ became substantially depleted $(<50 \mathrm{nM})$ and the rate of DMS production declined to zero, although the $\mathrm{DMSP}_{\mathrm{d}}$ pool was not completely exhausted. Furthermore, $\mathrm{DMSP}_{\mathrm{d}}$ consumption continued (although at reduced rates) well after DMS net production had stopped. The simplest explanation for this is that the rate of DMS consumption may have increased toward the end of the incubation as the DMS concentration increased. Net DMS production would appear to slow down while $\mathrm{DMSP}_{\mathrm{d}}$ consumption continued. However, this scenario is refuted by the results of the treatments containing competitive inhibitors where no DMS consumption could be detected. Net DMS production stopped, even in the presence of DMDS and MBE. A more plausible explanation is that other $\mathrm{DMSP}_{\mathrm{d}}$-consuming processes (including demethylation, biological oxidation or intracellular DMSP storage) dominate over the DMSP cleavage pathway at low DMSP concentrations. As the DMSP concentration decreased, the cleavage process would cease but DMSP uptake would continue. For example, in both mesocosms and in coastal waters, the relative importance of demethylation has been observed to increase during the declining phase of a phytoplankton bloom, as the $\mathrm{DMSP}_{\mathrm{d}}$ becomes exhausted (Kwint et al. 1996, van Duyl et al. 1998). It has been shown, based on ${ }^{35} \mathrm{~S}$ tracer studies (R. P. Kiene pers. comm.), that at low $\mathrm{DMSP}_{\mathrm{d}}$ concentrations the bacterial community requires all of the DMSP to satisfy its sulfur demand, and so demethylation processes dominate. At higher $\mathrm{DMSP}_{\mathrm{d}}$ concentrations where there is a surplus of sulfur, DMSP may be utilized simply as a carbon source and therefore the cleavage pathway becomes more significant. Visscher et al. (1992) reported that the DMSP-demethylating bacteria form a distinct population from the DMSP-cleavers but that does not exclude the possibility that the relative proportions or activities of the 2 groups might vary depending on the $\mathrm{DMSP}_{\mathrm{d}}$ concentration. It should be noted that in a recent study (Gonzalez et al. 1999), several strains of the Roseobacter group were isolated which exhibited both pathways, although the authors concluded that this dual-pathway trait was probably rare. 
It is the relative rates of cleavage and demethylation which determine the net yield of the DMSP to DMS conversion. This yield was calculated by comparing the DMS production to the rate of DMSP consumption. Averaged over the initial $40 \mathrm{~h}$ of the incubations, the ratio of the rate of DMS production to DMSP consumption in the samples amended with $100 \mathrm{nM} \mathrm{DMSP}_{\mathrm{d}}$ was typically in the range of 30 to $60 \%$ (mean $=45 \%$ ), indicating that the DMS production process in these experiments is relatively efficient. The values were generally lower in the unamended samples (mean $=35 \%$ ), but the difference was not statistically significant $(\mathrm{p}>$ $0.05, \mathrm{n}=11$ ). However, a relationship between DMS yield and $\mathrm{DMSP}_{\mathrm{d}}$ concentration has been observed in other studies (Gonzalez et al. 1999, Scarratt et al. 2000). In the present study, the lowest yields were observed at the Grand Banks station, which could be related to the low water temperature in that location compared to the other stations. While other authors have cited DMS production yields of $<30 \%$ and in some cases < $10 \%$ (Kiene \& Service 1991, Kiene 1992), it appears that in the North Atlantic, as much as half of the added $\mathrm{DMSP}_{\mathrm{d}}$ may be converted to DMS. However, this represents the net yield, and could reflect the low DMS consumption rates rather than any difference in the inherent efficiency of the DMSP-lyases in these samples. In an environment where DMS consumption was rapid, one would expect the overall net yield to be lower. It could also represent the effects of phytoplankton DMSP-lyases, since the incubations do not exclude phytoplankton. Similarly high net yields (exceeding $50 \%$ ) were recorded by Kwint et al. (1996) in a mesocosm system containing Phaeocystis sp., which is known to possess DMSP-lyase. However, neither of the 2 species known to possess this enzyme (Phaeocystis sp. and Emiliania huxleyii) were present in significant numbers at any of our stations, although the presence of dinoflagellates at 2 stations is a factor to consider since at least 1 species of Gyrodinium has been reported to show DMSP-lyase activity (Ishida 1968). If the overall conversion efficiencies measured here are representative of the open ocean, at least where the $\mathrm{DMSP}_{\mathrm{d}}$ concentration is high, it implies that the potential biological supply of DMS to the marine atmosphere could be more significant than might otherwise be supposed. It has been generally assumed that the vast majority of DMSP is degraded to other compounds such as 3-mercaptopropionate and methanethiol, and that most of the DMS which is produced is cycled within the water column. However, these experiments show that there could be situations where DMS production is high while DMS consumption is very low. Thus, substantial amounts of DMS may be available to be ventilated to the atmosphere, although the actual rate of ventilation will also depend on wind speed and water temperature, among other factors (Wanninkhof 1992, McGillis et al. 2000).

\section{DMSP $_{\mathrm{d}}$ consumption and DMS production in controls}

The rates of $\mathrm{DMSP}_{\mathrm{d}}$ consumption and DMS production in the control bottles of the long-term incubations give an approximation of the in situ rates in the water column, and are therefore central to any understanding of the importance of these processes in a given region. The net rates of both $\mathrm{DMSP}_{\mathrm{d}}$ consumption and DMS production in the control incubations were generally very low, and in some cases were indistinguishable from zero. Since these are net rates, this suggests that biological production and consumption of these compounds were nearly balanced in the surface waters. The exception was the North Atlantic Drift station, where significant net rates of $\mathrm{DMSP}_{\mathrm{d}}$ consumption and DMS production were measured (ca 1.0 and $0.3 \mathrm{nmol} \mathrm{l}^{-1} \mathrm{~d}^{-1}$ respectively). This indicates that production and consumption of $\mathrm{DMSP}_{\mathrm{d}}$ and DMS were not balanced at this station. This could be the result of DMSP consumption arising from $\mathrm{DMSP}_{\mathrm{d}}$ released by cell lysis during preparation and handling of the samples. Indeed, the initial $\mathrm{DMSP}_{\mathrm{d}}$ concentration in most of these incubations was higher than the in situ concentrations (ca 50\%). This effect was especially pronounced in the North Atlantic Drift, where the in situ $\mathrm{DMSP}_{\mathrm{p}}$ concentrations were relatively high (ca $30 \mathrm{nM}$ ), which tends to support the DMSP-release hypothesis. This is likely to be related to the species composition of the plankton community at that location, which was dominated by the dinoflagellates Gymnodinium sp. and Gyrodinium sp., both of which are known to produce DMSP (Keller et al. 1989). Since (as mentioned previously) Gyrodinium sp. may possess DMSP-lyase, DMS production may be further enhanced.

\section{DMS consumption rates}

DMS consumption in these incubations was undetectable using the inhibitor method. Since the net DMS production rates in unamended samples were also relatively low, this observation fits generally with those of Wolfe et al. (1999), who observed a direct correlation between the rates of DMS consumption and DMS production. As an independent test of the validity of these results, direct additions of DMS to water samples were also made at the Sargasso Sea and North Atlantic Drift stations, and produced similarly negligible consumption rates. It can therefore be safely concluded that the in situ DMS consumption rates at those 2 stations were 
indeed negligible and, by extension, it is reasonable to conclude that the undetectable DMS consumption rates in the other 2 long-term experiments are valid. Assuming that these stations were representative of their respective water masses, the implication is that bacterial DMS consumption is low across this part of the ocean at this time of year. Even when substantial quantities of DMS were introduced to the samples, the bacterial community could not consume DMS directly. Only at 1 station (the Chrysochromulina sp. bloom) was any consumption measurable, and then only in the DMS-amended samples. Chrysochromulina sp. is a known producer of DMSP (Keller et al. 1989), and possibly DMS as well, since other prymnesiophytes are known to possess DMSP-lyase. Its presence in the water column was accompanied by relatively high ambient levels of DMSP $_{\mathrm{p}}(79 \mathrm{nM})$ and DMS $(4.3 \mathrm{nM})$ compared with the surrounding stations. The bacterial cell population was also high at this station compared to the others. It is possible that the potential for bacterial consumption of DMS is elevated in waters where the ambient concentration of DMS is high. This could be explained if the induction period for bacterial DMS consumption were longer than the time-scale of these experiments. Bacterial populations which were adapted to high ambient DMS concentrations would therefore show measurable DMS consumption rates while bacteria from DMS-poor waters would show negligible rates.

\section{Relationship between potential rate constants and chl $a$}

To test whether the strong relationship between the potential rate constant $\left(k_{\mathrm{pot}}\right)$ and incubation temperature shown in Fig. 4A can be extrapolated to a wider geographic area, the data from this study were pooled with determinations of $k_{\text {pot }}$ made in the more northerly waters of the Labrador Sea $\left(48^{\circ}\right.$ to $\left.62^{\circ} \mathrm{N}\right)$ at approximately the same time of year using the same methodology (Schultes et al. 2000). Fig. 8A shows that the pooled data display no direct relationship between $k_{\text {pot }}$ and incubation temperature, and thus the relationship of Fig. 4A does not hold across a wider geographic range. In Fig. 8B, the pooled estimates of $k_{\text {pot }}$ are plotted against the concentration of chl $a$. In contrast to the limited data set of Fig. 4B, the pooled data show a significant relationship between $k_{\text {pot }}$ and chl $a$, in which $k_{\text {pot }}$ increases with increasing chl a concentration and reaches a maximum above $2 \mu \mathrm{g} \mathrm{l}^{-1}$. It is clear that $k_{\text {pot }}$ is related to the standing stock of phytoplankton in the water column, at least in waters where the standing stock is relatively low. This is intuitively reasonable since microbial abundance and activity are known to

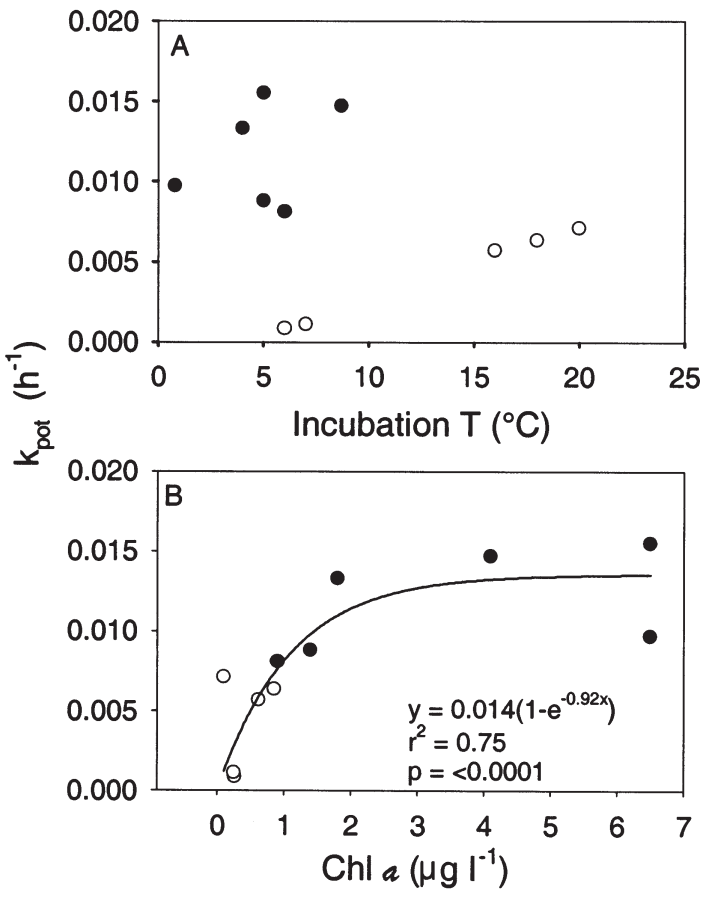

Fig. 8. Pooled potential rate constants $\left(k_{\mathrm{pot}}\right)$ from this study $(\mathrm{O})$ and from Schultes et al. (2000) (•). (A) Plot of $\left(k_{\text {pot }}\right)$ versus incubation temperature, showing no significant relationship; (B) relationship between $\mathrm{k}_{\text {pot }}$ and chlorophyll a concentration

be correlated with phytoplankton standing stock (Bird \& Kalff 1984, Cole et al. 1988). The relationship between $k_{\text {pot }}$ and chl a might be further bolstered if algal DMSP-lyases contribute significantly to the total lyase activity in seawater. Non-linear (inverse exponential) regression of the pooled data set shows a significant relationship $\left(\mathrm{r}^{2}=0.75, \mathrm{p}<0.0001\right)$ between $k_{\text {pot }}$ and chl a. The plateau at higher $\mathrm{chl}$ a concentrations indicates that $k_{\text {pot }}$ reaches a maximum in spite of increasing phytoplankton standing stock. This may be dependent on the species composition of the phytoplankton blooms in this region. However, this does not diminish the utility of the relationship in predicting $k_{\text {pot }}$ based on chl $a$. Since chl $a$ is easily measured remotely on synoptic scales, this finding could be of significant importance to efforts to model oceanic DMS production. The empirical prediction of rate constants from basic oceanographic variables would simplify the development of such models if the relationship shown here proves to be robust across a wider geographic and seasonal range.

\section{Conclusions}

Results from short-term kinetic incubations at 5 stations located in different areas of the North Atlantic 
show that the potential community DMS production in the open ocean is a linear function of $\mathrm{DMSP}_{\mathrm{d}}$ concentration and that it does not saturate, even at $\mathrm{DMSP}_{\mathrm{d}}$ concentrations as high as $3000 \mathrm{nM}$. Longer-term experiments indicate that $\mathrm{DMSP}_{\mathrm{d}}$ consumption rates were dependent on the concentration of $\mathrm{DMSP}_{\mathrm{d}}$, declining as the concentration declined. DMS production rates remained very constant as long as the dissolved DMSP substrate was present in sufficient quantities. Thus, the potential microbial DMS production following a phytoplankton bloom seems to be limited by the quantity of $\mathrm{DMSP}_{\mathrm{d}}$ released, not by the inherent capacity of the microbial community to metabolize DMSP. The net conversion yield of 30 to $60 \%$ indicates that cleavage was very significant compared to demethylation and other processes, but the continuation of DMSP $_{d}$ consumption after DMS production stopped suggests that demethylation and other processes dominate over DMSP cleavage at low $\mathrm{DMSP}_{\mathrm{d}}$ concentrations. DMS consumption was insignificant across much of the study area, although high consumption rates observed in a Chrysochromulina sp. bloom suggest that DMS consumption may be enhanced in areas where ambient DMS concentrations are high. While correlation between the potential rate constant $\left(k_{\text {pot }}\right)$ and water temperature was ambiguous, a significant non-linear relationship was found between $k_{\text {pot }}$ and chl a standing stock when the data from this study were pooled with those of Schultes et al. (2000) from the Labrador Sea. These findings are potentially useful for predictive modelling of oceanic DMS production.

Acknowledgements. The authors wish to thank the officers and crew of the CCGS 'Hudson'; François Roy and Delphine Thibault for assistance in the field and Lyse Bérard-Therriault for phytoplankton identification and enumeration. This work was funded by the Canadian Department of Fisheries and Oceans and grants from the Natural Sciences and Engineering Research Council of Canada to M.L., M.G., A.V. and S.J.dM.

\section{LITERATURE CITED}

Azam F, Ammerman JW (1984) Cycling of organic matter by bacterioplankton in pelagic marine ecosystems: microenvironmental considerations. In: Fasham MJR (ed) Flows of energy and materials in marine ecosystems. NATO Conf Ser 4, Vol 13. Plenum Press, New York, p 345-360

Azam F, Hodson RE (1981) Multiphasic kinetics for D-glucose uptake by assemblages of natural marine bacteria. Mar Ecol Prog Ser 6:213-222

Bates TS, Kiene RP, Wolfe GV, Matrai PA, Chavez FP, Buck KR, Blomquist BW, Cuhel RL (1994) The cycling of sulfur in surface seawater of the northeast Pacific. J Geophys Res 99:7835-7843

Bird DF, Kalff J (1984) Empirical relationships between bacterial abundance and chlorophyll concentration in fresh and marine waters. Can J Fish Aquat Sci 41:1015-1023
Blackburn N, Azam F, Hagström ^̊ (1997) Spatially explicit simulations of a microbial food web. Limnol Oceanogr 42: 613-622

Blackburn N, Fenchel T, Mitchell J (1998) Microscale nutrient patches in planktonic habitats shown by chemotactic bacteria. Science 282:2254-2256

Bowen JD, Stolzenbach KD, Chisholm SW (1993) Simulating bacterial clustering around phytoplankton cells in a turbulent ocean. Limnol Oceanogr 38:36-51

Cantin G, Levasseur M, Gosselin M, Michaud S (1996) Role of zooplankton in the mesoscale distribution of surface dimethylsulfide concentrations in the Gulf of St. Lawrence, Canada. Mar Ecol Prog Ser 141:103-117

Cantin G, Levasseur M, Schultes S, Michaud S (1999) Dimethylsulfide production by size-fractionated particles in the Labrador Sea. Aquat Microb Ecol 19:307-312

Charlson RJ, Lovelock JE, Andreae MO, Warren SG (1987) Oceanic plankton, atmospheric sulphur, cloud albedo and climate. Nature 326:655-661

Clarke AD, Davis D, Kapustin VN, Eisele F, Chen G, Paluch I, Lenschow D, Bandy AR, Thornton D, Moore K, Maudlin L, Tanner D, Litchy M, Carrol MA, Collins J, Albercook G (1998) Particle nucleation in the tropical boundary layer and its coupling to marine sulfur sources. Science 282: $89-92$

Cole JJ, Findlay S, Pace ML (1988) Bacterial production in fresh and saltwater ecosystems: a cross-system overview. Mar Ecol Prog Ser 43:1-10

Dacey JW, Howse HFA, Michaels AF, Wakeham SG (1998) Temporal variability of dimethylsulfide and dimethylsulfoniopropionate in the Sargasso Sea. Deep-Sea Res (Part 1 Oceanogr Res Pap) 45:2085-2104

de Souza MP, Yoch DC (1995a) Purification and characterization of dimethylsulfoniopropionate lyase from an Alcaligenes-like dimethyl sulfide-producing marine isolate. Appl Environ Microbiol 61:21-26

de Souza MP, Yoch DC (1995b) Comparative physiology of dimethyl sulfide production by dimethylsulfoniopropionate lyase in Pseudomonas doudorofii and Alcaligenes sp. strain M3A. Appl Environ Microbiol 61:3986-3991

Falkowski PG, Kim Y, Kolber Z, Wilson C, Wirik C, Cess W (1992) Natural versus anthropogenic factors affecting lowlevel cloud albedo over the North Atlantic. Science 256: 1311-1313

Gabric A, Murray N, Stone L, Kohl M (1993) Modelling the production of dimethyl sulfide during a phytoplankton bloom. J Geophys Res 98:22805-22816

Gonzalez JM, Kiene RP, Moran MA (1999) Transformation of sulfur compounds by an abundant lineage of marine bacteria in the $\alpha$-subclass of the class Proteobacteria. Appl Environ Microbiol 65:3810-3819

Ishida Y (1968) Physiological studies on the evolution of dimethyl sulfide from unicellular marine algae. Mem Coll Agric Kyoto Univ 94:47-82

Jonkers HM, Koopmans GF, van Gemerden H (1998) Dynamics of dimethyl sulfide in a marine microbial mat. Microb Ecol 36:93-100

Keller MD, Bellows WK, Guillard RRL (1989) Dimethyl sulfide production in marine phytoplankton. In: Saltzman ES, Cooper WJ (eds) Biogenic sulfur in the environment. American Chemical Society, Washington, p 167-182

Kettle AJ, and 31 others (1999) A global database of sea surface dimethylsulfide (DMS) measurements and a procedure to predict sea surface DMS as a function of latitude, longitude and month. Global Biogeochem Cycles 1: 399-444

Kiene RP (1990) Dimethyl sulfide production from dimethyl- 
sulfoniopropionate in coastal seawater samples and bacterial cultures. Appl Environ Microbiol 56:3292-3297

Kiene RP (1992) Dynamics of dimethyl sulfide and dimethylsulfoniopropionate in oceanic water samples. Mar Chem 37:29-52

Kiene RP, Bates TS (1990) Biological removal of dimethyl sulphide from sea water. Nature 345:702-705

Kiene RP, Service SK (1991) Decomposition of dissolved DMSP and DMS in estuarine waters: dependence on temperature and substrate concentration. Mar Ecol Prog Ser $76: 1-11$

Kuennis K (1998) Development of microbial community during Skeletonema costatum detritus degradation. Hydrobiologia 363:253-260

Kwint RLJ, Kramer KJM (1995) Dimethylsulphide production by phytoplankton communities. Mar Ecol Prog Ser 121: 227-237

Kwint RLJ, Quist P, Hansen TA, Dijkhuizen L, Kramer KJM (1996) Turnover of dimethylsulfoniopropionate and dimethylsulfide in the marine environment: a mesocosm experiment. Mar Ecol Prog Ser 145:223-232

Leck C, Bågander LE (1988) Determination of reduced sulfur compounds in aqueous solutions using gas chromatography and flame photometric detection. Anal Chem 60: 1680-1683

Ledyard KM (1993) Marine microbial production of dimethylsulfide from dissolved dimethylsulfoniopropionate. Doctoral dissertation. WHOI-93-07. Woods Hole Oceanographic Institution, Woods Hole, MA

Ledyard KM, Dacey JWH (1994) Dimethylsulfide production from dimethylsulfoniopropionate by a marine bacterium. Mar Ecol Prog Ser 110:95-103

Ledyard KM, Dacey JWH (1996) Microbial cycling of DMSP and DMS in coastal and oligotrophic seawater. Limnol Oceanogr 41:33-40

Ledyard KM, de Long EF, Dacey JW (1993) Characterization of a DMSP-degrading bacterial isolate from the Sargasso Sea. Arch Microbiol 160:312-318

Legrand M (1997) Ice-core records of atmospheric sulphur. Phil Trans R Soc (Ser B) 352B:241-250

Legrand M, Hammer C, De Angelis M, Savarino J, Delmas R, Clausen H, Johnsen SJ (1997) Sulfur-containing species (methanesulfonate and $\mathrm{SO}_{4}{ }^{2-}$ ) over the last climatic cycle in the Greenland Ice Core Project (central Greenland) ice core. J Geophys Res 102:26663-26679

Levasseur M, Michaud S, Egge J, Cantin G, Nejstgaard JC, Sanders R, Fernandez E, Solberg PT, Heimdal B, Gosselin M (1996) Production of DMSP and DMS during a mesocosm study of an Emiliania huxleyi bloom: influence of bacteria and Calanus finmarchicus grazing. Mar Biol 126:609-618

Logan BE, Fleury RC (1993) Multiphasic kinetics can be an artifact of the assumption of saturable kinetics for microorganisms. Mar Ecol Prog Ser 102:115-124

Longhurst A (1995) Seasonal cycles of pelagic production and consumption. Prog Oceanogr 35:77-167

Malin G, Turner S, Liss P, Holligan P, Harbour D (1993) Dimethylsulphide and dimethylsulphoniopropionate in the Northeast Atlantic during the summer coccolithophore bloom. Deep-Sea Res 40:1487-1508

Matrai PA, Vernet M (1997) Dynamics of the vernal bloom in the marginal ice zone of the Barents Sea: dimethyl sulfide and dimethylsulfoniopropionate budgets. J Geophys Res 102:22965-22979

McGillis WR, Dacey JWH, Frew NM, Bock EJ, Nelson RK (2000) Water-air flux of dimethylsulfide. J Geophys Res 105:1187-1193
Mitchell JG, Okubo A, Fuhrman JA (1985) Microzones surrounding phytoplankton form the basis for a stratified marine microbial system. Nature 316:58-59

Nissen H, Nissen P, Azam F (1984) Multiphasic uptake of D-glucose by an oligotrophic marine bacterium. Mar Ecol Prog Ser 16:155-160

Palmer Locarnini SJ, Turner SM, Liss PS (1998) The distribution of dimethylsulfide, DMS, and dimethylsulfoniopropionate, DMSP, in waters off the Western Coast of Ireland. Cont Shelf Res 18:1455-1474

Parsons TR, Maita Y, Lalli CM (1984) A manual of chemical and biological methods of seawater analysis. Pergamon Press, Oxford

Porter KG, Feig YS (1980) The use of DAPI for identifying and counting aquatic microflora. Limnol Oceanogr 25:943-948

Scarratt M, Cantin G, Levasseur M, Michaud S (2000) Particle size-fractionated kinetics of DMS production: where does DMSP cleavage occur at the microscale? J Sea Res 43: $245-252$

Schultes S, Levasseur M, Michaud S, Cantin G, Wolfe G, Gosselin M, de Mora S (2000) Dynamics of dimethylsulfide production from dissolved dimethylsulfoniopropionate in the Labrador Sea. Mar Ecol Prog Ser 202:27-40

Šimek K, Vrba J, Pernthaler J, Posch T, Hartman P, Nedoma J, Psenner R (1997) Morphological and compositional shifts in an experimental bacterial community influenced by protists with contrasting feeding modes. Appl Environ Microbiol 63:587-595

Stefels J, Dijkhuizen L (1996) Characteristics of DMSP-lyase in Phaeocystis sp. (Prymnesiophyceae). Mar Ecol Prog Ser 131:307-313

Steinke M, Wolfe GV, Kirst GO (1998) Partial characterization of dimethylsulfoniopropionate (DMSP) lyase isozymes in 6 strains of Emiliania huxleyi. Mar Ecol Prog Ser 175: 215-225

van Duyl FC, Gieskes WWC, Kop AJ, Lewis WE (1998) Biological control of short-term variations in the concentration of DMSP and DMS during a Phaeocystis spring bloom. J Sea Res 40:221-231

Visscher PT, Taylor BF (1993) A new mechanism for the aerobic catabolism of dimethyl sulfide. Appl Environ Microbiol 59:3784-3789

Visscher PT, Diaz MR, Taylor BF (1992) Enumeration of bacteria which cleave or demethylate dimethyl-sulfoniopropionate in the Caribbean Sea. Mar Ecol Prog Ser 89: 293-296

Wanninkhof R (1992) Relationship between wind speed and gas exchange over the ocean. J Geophys Res 97: 7373-7382

Wolfe GV (1996) Accumulation of dissolved DMSP by marine bacteria and its degradation via bacterivory. In: Kiene RP, Visscher PT, Keller MD, Kirst GO (eds) Biological and environmental chemistry of DMSP and related sulfonium compounds. Plenum Press, New York, p 277-291

Wolfe GV, Kiene RP (1993) Effects of methylated, organic and inorganic substrates on microbial consumption of dimethyl sulfide in estuarine waters. Appl Environ Microbiol 59:2723-2726

Wolfe GV, Levasseur M, Cantin G, Michaud S (1999) Microbial consumption and production of dimethyl sulfide (DMS) in the Labrador Sea. Aquat Microb Ecol 18: 197-205

Yoch D, Ansede J, Rabinowitz K (1997) Evidence for intracellular and extracellular dimethylsulfoniopropionate (DMSP) lyases and DMSP uptake sites in two species of marine bacteria. Appl Environ Microbiol 63:3182-3188 